\title{
On the Use of Sterilisation Bonds in Emerging Asia ${ }^{1}$
}

\author{
Aaron Mehrotra \\ Bank for International Settlements
}

This version: January 9, 2012

\begin{abstract}
We document recent developments in the use of sterilisation bonds by six central banks in emerging Asia, and discuss the implications for monetary policy and the financial sector. For most economies in the sample, the rapid increase of net foreign assets in central banks' balance sheets has been sterilised by issuing central banks' own paper. There has been an attempt to lengthen the maturity structure of the sterilisation bills, and maturities have risen especially in 2010-11. An econometric exercise suggests that higher inflation and stronger portfolio capital inflows are positively associated with the length of the maturities of issued sterilisation paper for some economies. Moreover, the amount of liquidity absorbed by issuing central bank paper tends to increase relative to that locked up by reserve requirements when credit growth is strong. The relative costs of using these tools appear to matter less for the choice of sterilisation instrument.
\end{abstract}

Keywords: sterilisation bond; central bank bonds and bills; foreign exchange reserves; emerging Asia

JEL classification: E43, E50, E52, E58.

\section{Introduction}

Since the Asian crisis, central banks in emerging Asia have accumulated large reserves in order to protect against a run in the currency and to provide assurance to markets about the sustainability of the exchange rate regime. The experience from the international financial crisis largely vindicated this policy, as central banks had considerable leeway to run down their assets in face of depreciation pressures. Indeed, foreign exchange reserves in the region shrank at the end of 2008, perhaps most prominently in India, Korea and Malaysia. During the subsequent recovery, as inflation pressures rose, emerging market central banks were generally more favourable to increased exchange rate flexibility, in particular letting their exchange rates appreciate. Within major emerging economies in Asia, the rates of appreciation against the USD in 2010 ranged from 2.5 percent (Korea) to 9.9 percent

\footnotetext{
1 Author correspondence: Aaron Mehrotra, Bank for International Settlements, Centralbahnplatz 2, $\mathrm{CH}-4002$ Basel, Switzerland. Email: aaron.mehrotra@bis.org. All opinions are those of the author and do not necessarily represent those of the Bank for International Settlements. I am grateful to Guonan Ma, Madhusudan Mohanty, Philip Turner and James Yetman for their insightful comments. Marjorie Santos BesImeisl provided excellent research assistance.
} 
(Malaysia). ${ }^{2}$ However, due to continued resistance to full flexibility of the exchange rate, foreign exchange reserves have continued to accumulate in an environment of persistent current account surpluses and in most cases strong capital inflows. ${ }^{3}$

The ballooning reserves have led to significant increases in central bank balance sheets, with implications for overall macroeconomic and financial stability. ${ }^{4}$ In order to maintain monetary stability, central banks in the region have largely sterilised the interventions in the foreign exchange markets by both non-market and market-based approaches. The former include the use of reserve requirements, the compulsory transfer of public institutions' deposits to the central bank and direct controls on bank lending; the latter encompasses sterilisation bonds (either government or central bank paper), foreign exchange swaps, repo agreements and direct borrowing from banks through an overnight deposit facility.

In this paper, we describe the recent use of one market-based approach to sterilised intervention, the issuance of sterilisation bonds, in emerging Asia. As discussed by Filardo and Grenville (2011), an important development in the process of sterilisation of recent years has been the issuance of central banks' own paper. While some central banks in the region have a longer history in using central bank paper for sterilisation purposes (Indonesia, Korea), its use has increased notably in the recent past. In addition to concerns about financial disintermediation that some non-market based measures could entail, the issuance of central bank bills could help deepen the local bond market and further develop a yield curve. There has been an attempt to lengthen the maturity structure, in order to enhance monetary control, and possibly discourage an increase of short-term positions in sterilisation paper by foreign investors in an environment of heavy capital inflows. In most jurisdictions, maturities dropped during the crisis in the face of capital outflows, and lengthened across the board in 2010-11.

The choice of a particular sterilisation instrument depends, inter alia, on the prevailing economic and financial conditions. In order to investigate under which conditions liquidity absorption takes place through the issuance of sterilisation paper, rather than through increases in reserve requirements, we specify an econometric model relating liquidity absorption to various macroeconomic and financial factors. We find that stronger credit growth is positively associated with increased liquidity absorption via the issuance of sterilisation bonds for some emerging Asian economies. In contrast, both methods of sterilisation seem to be equally important when the economy is faced with capital inflows. Moreover, the maturities on central bank paper tend to increase when inflation picks up, suggesting that monetary stability considerations are important for the chosen maturity structure.

This paper is structured as follows. Section 2 discusses the use of sterilisation bills in the context of a central bank's balance sheet, and mentions the implications of the use of this instrument for monetary policy and the financial sector as a whole. Section 3 provides a descriptive analysis about the use of sterilisation bonds in emerging Asia. This is followed by an econometric exercise linking the use of sterilisation instruments to the prevailing macroeconomic and financial conditions in Section 4. The final section concludes with policy implications.

\footnotetext{
${ }^{2}$ The Hong Kong dollar is an exception to this general trend, as it is pegged to the USD via the currency board arrangement - the linked exchange rate system.

${ }^{3}$ While a mercantilist policy could in principle explain the accumulation of reserves, Aizenman and Lee (2007) find that empirical evidence supports precautionary rather than mercantilist motives after the Asian crisis.

${ }^{4}$ From a policy framework perspective, there has arguably been a re-emergence of the importance of quantities, whereby the central bank assets and liabilities structure could play an important role in policy, over and above the short-term policy interest rate.
} 


\section{The implications of sterilisation bond issuance for monetary policy and the financial sector}

The accumulation of reserves and the sterilisation procedure can be discussed in the context of the central bank's balance sheet. ${ }^{5}$ Table 1 provides a stylized version of the balance sheet. The central bank's assets are comprised of net foreign and domestic assets, and its liabilities include monetary liabilities (currency and bank reserves), non-monetary liabilities (central bank securities and others) and equity capital. Equity capital includes the government transfers to the central bank, coupled with any accumulated profits or losses. The increase in foreign exchange reserve assets is financed by liabilities within the domestic financial system. Of these liabilities, currency is usually assumed to be determined by the public's demand for cash balances. Strong growth in emerging Asia has implied an increase in the amount of currency in circulation in the region, while bank reserves have risen partly on the back of increased reserve requirements by many central banks to mop up excess liquidity.

Table 1

A central bank's balance sheet

\begin{tabular}{l|l}
\hline \multicolumn{1}{c|}{ Assets } & \multicolumn{1}{c}{ Liabilities } \\
\hline Net foreign assets & Monetary liabilities \\
Net domestic assets & Currency \\
& Non-monetary liabilities \\
& - Central bank securities \\
& Others \\
& Equity capital \\
\hline
\end{tabular}

If equity capital is unchanged, and the demand for currency remains constant, reserve accumulation results in a financing need for the central bank. This financing need can be captured by the excess of foreign exchange reserves over currency in circulation. Graph 1 shows this financing need as a ratio of foreign exchange reserves less currency as a percentage of the size of the overall financial system in the major emerging regions (including China and India). Graphs A1 and A2 in the Appendix display these measures for the other economies in our sample. As the financing need becomes large, the central bank's financing operations are likely to have an important impact on the financial system.

\footnotetext{
${ }^{5}$ The balance sheet discussion draws on BIS (2009) and Mohanty and Turner (2006).
} 


\section{Graph 1}

\section{Foreign exchange reserves minus currency held by the public}

As a percentage of:

(a) $\mathrm{M} 1^{1}$

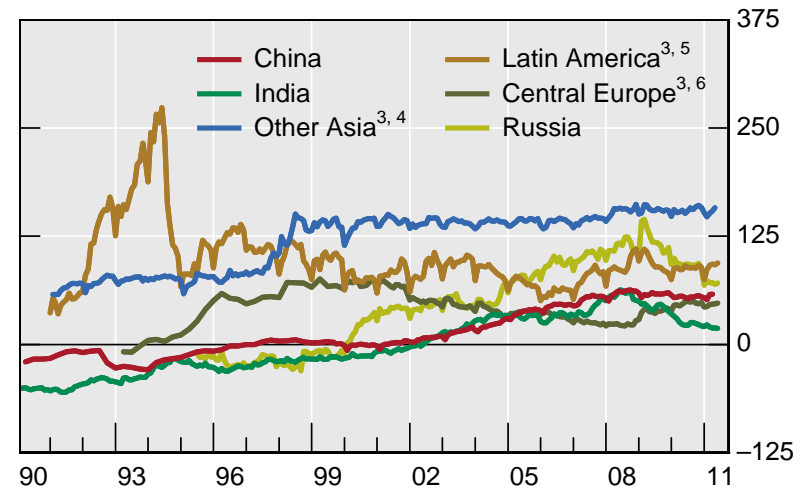

(c) Bank credit to the private sector

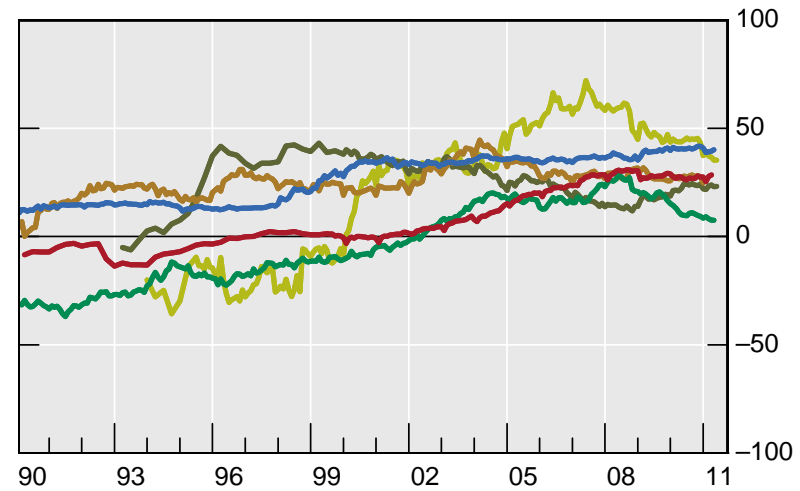

(b) $\mathrm{M}^{2}$

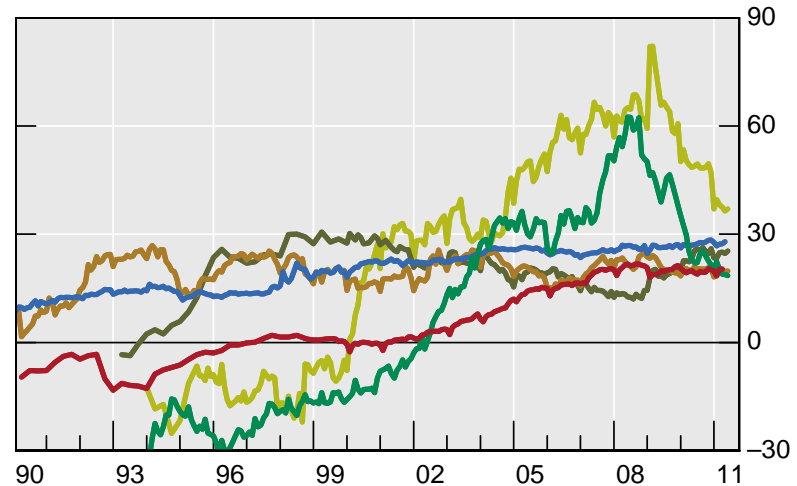

(d) Public sector domestic debt securities

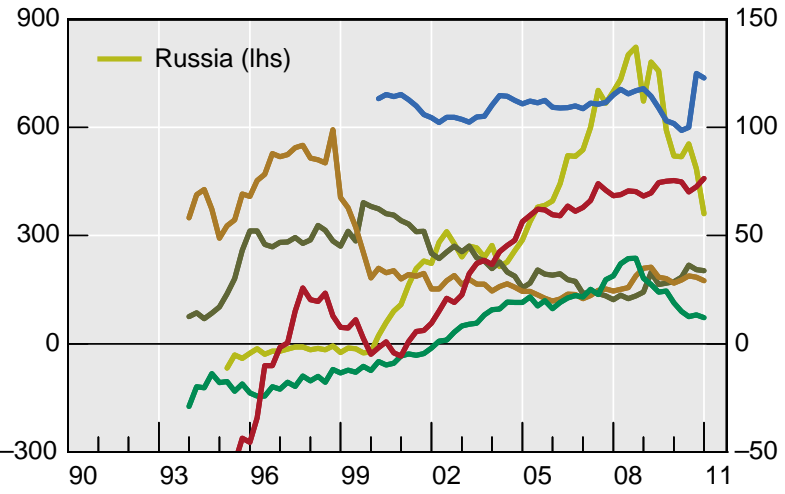

${ }^{1} \mathrm{M} 1$, also called narrow money, comprises transferable deposits and currency outside deposit money banks. 2 M2 is a broad measure of money which in general comprises, in addition to M1, time, savings and foreign currency deposits of resident sectors other than central government. The components can vary across economies. ${ }^{3}$ Weighted average of the economies listed, based on 2005 GDP and PPP exchange rates. ${ }^{4}$ Chinese Taipei, Hong Kong SAR, Indonesia, Korea, Malaysia, the Philippines, Singapore and Thailand. $\quad{ }^{5}$ Argentina, Brazil, Chile, Colombia, Mexico, Peru and Venezuela. ${ }^{6}$ The Czech Republic, Hungary and Poland.

Sources: IMF; Datastream; national data; BIS.

The central bank tackles the financing need by issuing domestic monetary liabilities. If the central bank has a target for the short-term interest rate, it cannot allow the increased monetary reserves to lead to increased bank credit and inflation pressures. In such a case, it typically sells domestic assets (although these may be limited relative to the size of the required amount) or issues its own securities to offset the increase in bank reserves. This sterilised intervention can take place either using market (sterilisation securities; direct borrowing from banks; repo transactions; foreign exchange swaps) or non-market based instruments (direct controls on bank lending; reserve requirements; shifting deposits to central bank). There is substantial evidence in the literature to suggest that a large part of intervention has been sterilised in most economies where intervention has taken place (see eg Mohanty and Turner, 2006; Aizenman and Glick, 2009). ${ }^{6}$

\footnotetext{
${ }^{6}$ For China, Oyuang et al. (2007) find that roughly $90 \%$ of reserve accumulation was sterilised during 1999-2005; $\mathrm{He}$ et al. (2005) also suggest that sterilisation has been effective.
} 
An obvious benefit of using market-based instruments such as sterilisation bonds over nonmarket based measures is that central banks are able to withdraw liquidity without creating market distortions or disintermediation in parts of the financial system. This stands in contrast to the use of reserve requirements that may cause lending to be directed away from banks or the domestic financial system more generally. If borrowing by domestic firms is redirected to banks abroad, sterilisation becomes ineffective, and the riskiness of the domestic financial system may increase. Indeed, to the extent that the central bank does not pay a market interest rate to remunerate reserves, reserve requirements act as a tax on the domestic banking system. Reinhart and Reinhart (1999) show that changes in reserve requirements may impact the real exchange rate. If the central bank increases reserve requirements to sterilise its intervention, and depositors pay the tax, domestic deposits become less attractive. If borrowers pay the tax instead, loans become more expensive - in both cases depreciation pressure on the real exchange rate may ensue. Moreover, depending on the incidence of the tax, there may be effects on domestic spending and production.

What are the implications of sterilised intervention by issuing sterilisation paper for monetary policy and the financial system in general? From the viewpoint of monetary policy, sterilisation may be more effective if households and non-bank firms are the ultimate holders of the sterilisation paper and this paper is long term. The impact of foreign exchange interventions on base money can be fully sterilised simply as commercial banks buy sterilisation paper from the central bank. However, as discussed later in this section, central bank paper is a relatively liquid asset, and its ownership by commercial banks might do little to restrain lending in the economy. Moreover, if the origin of the currency appreciation and the foreign exchange intervention is a current account surplus, foreign exchange earnings by exporters have initially likely created a bank deposit. As the commercial bank sells the foreign exchange proceedings to the central bank and receives the sterilisation bond in return, it maintains the deposit and holds the sterilisation bill. Only if non-banks subsequently purchase the sterilisation bond by drawing down on their deposits, would broad money be reduced.

Non-banks' ownership of sterilisation paper is more likely to take place if the sterilisation paper markets are liquid and long-term paper is available. As sterilisation bond markets have deepened and central banks have aimed at replacing short-term paper with longer maturities, these conditions have arguably strengthened in recent years in the Asian region. Filardo and Grenville (2011) show that the correlation between the growth in central bank assets and reserve money has been basically zero in emerging Asia in the 2000 s, with virtually no impact on the inflation rate. Therefore, the monetary effect of reserve accumulation was effectively sterilised.

The use of market-based paper for sterilisation purposes may prove to be counterproductive for monetary policy in some cases. If the central bank sterilises strong capital inflows by issuing short-term securities, foreign investors may be encouraged to take short-term positions in the currency using sterilisation paper. Thus, the issuance of short-term sterilisation paper could in fact encourage capital inflows and threaten the success of sterilisation. The issuance of short-term paper may also create interest rate risks for the central bank. As the need for future liquidity absorbing operations increases, there could be a heavy interest cost burden if domestic interest rates rise. Large sterilised intervention by means of issuing securities may also damage the credibility of domestic monetary policy. The central bank may be unwilling to tighten policy sufficiently when faced with inflationary pressures, as the costs of sterilisation increase when the difference between local and foreign interest rates increases. This could lead to an inflationary bias in policy over time.

For the financial system, the increased use of sterilisation bonds could be seen as helpful in developing and deepening the local debt markets. In an emerging economy, bond issuance could help develop a yield curve. But such a process is endogenous, as the tendency to resort to market-based measures of sterilisation increases as local bond markets deepen. With thin markets, market-based measures may cause big fluctuations in domestic interest 
rates. As noted by Mohanty and Turner (2006), the low interest rate environment has likely played a role in the increased use of market-based sterilisation measures. Despite the recent pickup in inflation in emerging markets, improved monetary control and higher central bank independence suggest that this factor is likely to contribute to the use of market-based tools for sterilisation in the region.

Bank lending behaviour could be affected if banks hold large volumes of sterilisation bonds, as discussed by Sang Kuang (2008). The perception of sterilisation bonds as a source of risk-free profits could curtail bank lending to the private sector, reducing productive investment. Indeed, Cook and Yetman (2011) find that there is a negative relationship between increases in foreign reserve holdings and the growth rate of bank lending for banks in some economies in emerging Asia. Further, CGFS (2007b) documents that commercial banks hold almost one-half of local currency government paper outstanding in emerging markets.

The liquidity characteristic of sterilisation bonds may play an important role in determining the impact on the bank lending channel. If banks perceive sterilisation bonds as very liquid assets, and the ownership of liquid assets has a positive impact on lending, banks may be inclined to extend loans to the non-bank private sector even when holding substantial amounts of sterilisation bills, running counter to the ultimate aim of sterilisation. ${ }^{7}$ Similarly, if there is easy access to wholesale funding, credit growth may be rapid despite sterilisation. In contrast, if no profitable lending opportunities are available for the commercial banks, the monetary authority may lower the interest rate on the sterilisation bonds that the commercial banks hold and therefore lower the costs of sterilisation (Filardo and Grenville, 2011). Over time such a process encourages the commercial banks to seek new lending opportunities, possibly with higher risk. Alternatively, if the commercial banks are state-owned, the monetary authority may be able to conduct sterilisation operations at a lower cost than when dealing with privately-owned banks. This could be a relevant issue when considering sterilisation costs in China, for example.

The liquidity characteristic of sterilisation bonds as influencing commercial banks' lending behaviour could prove irrelevant, however, if the end-holders are non-residents. In some economies in the region, such as Indonesia and Malaysia, an important share of central bank securities are held by non-residents. Such descriptive evidence from emerging Asia is discussed further in the next section.

\section{Descriptive evidence on the issuance of sterilisation bonds in emerging Asia}

Central banks in emerging Asia have been increasingly using their own securities for sterilisation purposes. In this section, we provide a descriptive analysis about the use of sterilisation bonds in six emerging Asian economies. Five of them (China, Indonesia, Korea, Malaysia and Thailand) issue central bank bills, while one (India) issues government and other securities under a separate account held at the central bank solely for sterilisation purposes. Graph 2 shows the outstanding amounts of central bank securities for the six economies in our sample, as shares of GDP. Outstanding amounts in national currency are displayed in Graph A3 in the Appendix.

\footnotetext{
${ }^{7}$ Kumhof (2004) presents a theoretical model featuring the possibility that sales of sterilisation bonds at high interest rates actually raise consumption demand.
} 


\section{Central bank securities ${ }^{1}$}

As a percentage of $\mathrm{GDP}^{2}$
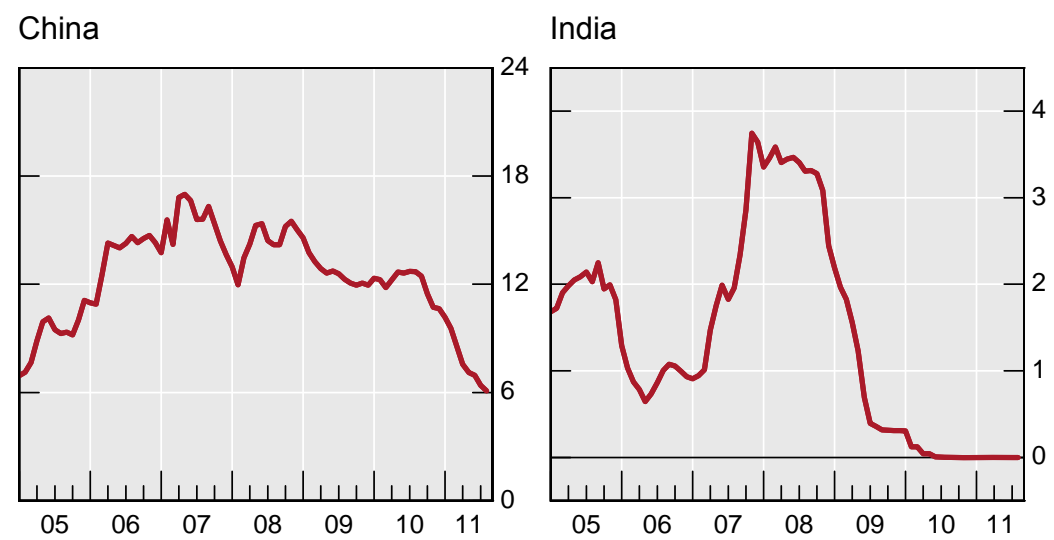

Indonesia

Korea

Malaysia
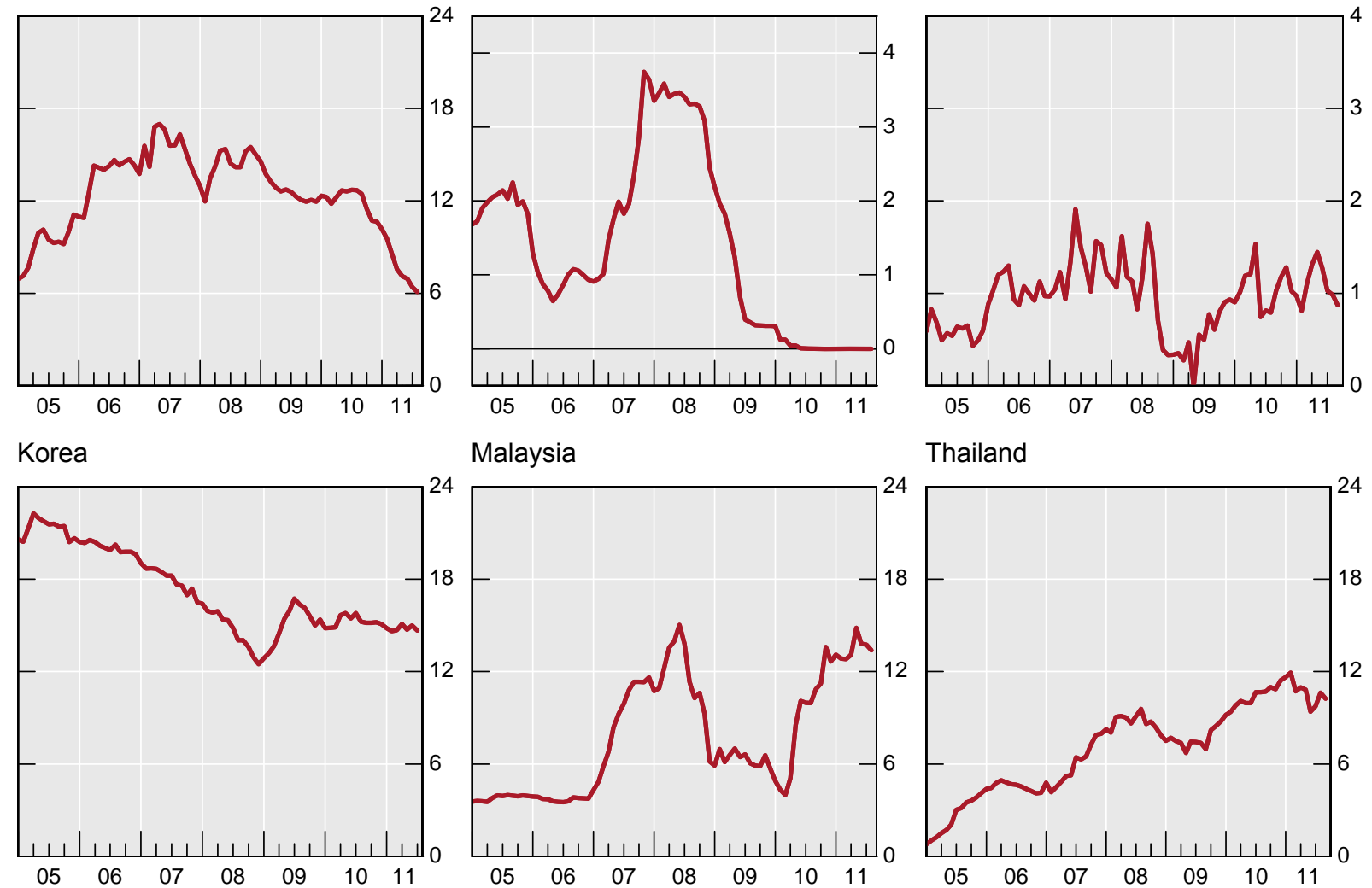

Thailand

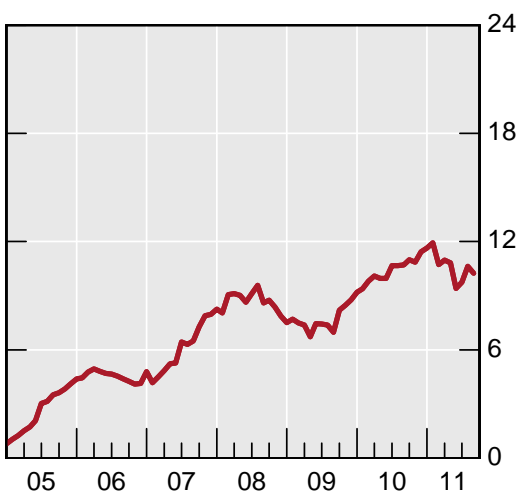

1 For India, proceeds from auctions of treasury bonds and securities under the market stabilization scheme, deposited at the Reserve Bank of India. 2 The scaling variable used is annual GDP data converted to monthly using linear interpolation.

Sources: IMF; CEIC.

In Korea, sterilisation bonds (monetary stabilisation bills, MSBs) were issued for the first time in 1961, and their importance as a tool to remove excess liquidity increased especially after the Asian crisis. As a share of GDP, outstanding central bank securities amounted to $20 \%$ of GDP still in 2005 (highest in our sample). The share has since declined but still amounted to roughly $15 \%$ of GDP in 2011 . In national currency terms, the outstanding volume in 2005 was similar to that in 2011. In contrast to many other Asian economies, non-market based approaches, such as changes in the reserve requirement ratio, have not played an important role in Korea (see Table A4 in Mohanty and Turner, 2006). The issuance of central bank bills for sterilisation was commenced already prior to the Asian crisis in Indonesia as well (Bank Indonesia Certificates, SBIs). As a share of GDP, the amount of central bank securities has hovered between 0 and $2 \%$ in recent years.

In China, the issuance of central bank bills started somewhat later, and their use has coincided with several other instruments for sterilisation, including reserve requirements, open market operations of special government bonds and currency swaps with commercial 
banks. $^{8}$ The People's Bank of China started to issue three-month, six-month and one-year central bank bills in 2003. Longer-term (3-year) bills were issued from December 2004 onwards. In the case of China, market-based issuance of sterilisation bonds has been combined with targeted issuance - bills targeted at those commercial banks that experienced a rapid growth in credit and fairly abundant liquidity. In 2010-2011, the outstanding amount of central bank securities has fallen in both nominal terms and as a share of GDP, standing roughly at $6 \%$ of GDP in mid-2011. In 2006-2008, their share was close to $15 \%$ of GDP.

Both Malaysia and Thailand use a variety of instruments for liquidity management. In the case of Malaysia, interventions are sterilised using direct borrowing, repos and the issuance of Bank Negara Malaysia Monetary Notes (BNMNs). Over time, policy has shifted towards the use of repo operations and BNMNs (Sang Kuang, 2008). The Bank Negara Malaysia introduced the BNMNs in December 2006 in order to gradually replace the Bank Negara Bills (BNBs) and Bank Negara Negotiable Notes for managing liquidity. ${ }^{9}$ We consider the Bank of Negara Malaysia Monetary Notes/Bank Negara Bills (BNMNs/BNBs) as the relevant sterilisation bonds. As a share of GDP, the volume of outstanding central bank securities more than doubled during 2011 and now stands at above 13\% of GDP (Graph 2). For Thailand, the sterilisation bond of interest here is the central bank (BOT) bond, which is the principal absorption instrument (Bank of Thailand, 2009, p. 73). Thaicharoen and Ananchotikul (2008) note that BOT bonds are efficient in absorbing liquidity on a large scale with longer maturities. For this economy as well, central bank bonds are accompanied by repo transactions and foreign exchange swaps in the management of liquidity. Central bank securities have been slowly increasing as a share of GDP and now stand at close to $10 \%$.

In the case of India, the Reserve Bank is not allowed to issue its own securities. Large capital inflows were traditionally managed through the day-to-day Liquidity Adjustment facility (LAF), in particular its repo and reverse repo auctions, and supplemented by outright sales of government securities by open market operations (Mohan, 2008). Liquidity was also absorbed by increasing the surplus balances of the government with the Reserve Bank. However, given the limited stock of government securities, India adopted a new instrument in 2004. This Market Stabilisation Scheme (MSS) is solely used for sterilisation purposes. Under the scheme, the Reserve Bank may issue government Treasury Bills and mediumterm dated securities. The proceeds from the auctions are placed on a separate MSS cash account that is maintained and operated by the Reserve Bank. MSS has become the instrument for medium-term liquidity management, leaving LAF for the management of liquidity on a daily basis.

\footnotetext{
${ }^{8} \mathrm{~A}$ non-market based tool that has been very prominent during the recovery is the required reserve ratio (see Ma et al., 2011). During January-June 2011, China increased reserve requirements for large banks six times (a total of eleven times since the start of 2010). In the fall of 2011, reserve requirements were reported to be extended to cover banks' margin deposits, further draining liquidity. Graph 2 suggests that the relative importance of central bank bills as a sterilisation instrument has decreased during 2010-11.
}

${ }^{9}$ See http://www.bnm.gov.my/index.php?ch=8\&pg=14\&ac=1349 . 


\section{Table 2}

Management of liquidity in India by market stabilisation scheme (MSS) and cash reserve ratio (CRR)

\begin{tabular}{|c|c|c|c|c|}
\hline & $2007-08$ & $2008-09$ & $2009-10$ & $2010-11$ \\
\hline $\begin{array}{c}\text { Liquidity impact } \\
\text { of MSS }\end{array}$ & 1054.2 & 803.1 & 853.4 & 27.4 \\
\hline $\begin{array}{c}\text { First-round } \\
\text { impact of CRR } \\
\text { change }\end{array}$ & -470.0 & 1022.5 & -360.0 & -125.0 \\
\hline
\end{tabular}

A positive sign indicates an injection of liquidity into the banking system.

Source: Macroeconomic and Monetary Developments Quarterly Review, several issues.

In contrast to other economies where the stock of issued central bank securities has been growing over time, in India the amount of MSS outstanding was drawn down quickly during 2009 and 2010, as surplus liquidity was low (Graph 2). Table 2 shows that liquidity management operations by the MSS resulted in an injection of liquidity from the financial year 2007-08 through 2010-11. In contrast, adjustments of the cash reserve ratio (CRR), in line with tightened policy stance in an inflationary environment, resulted in absorptions of liquidity for all other years except 2008-09. ${ }^{10}$

Some central banks have aimed at lengthening the maturity of the issued sterilisation bills. For instance, the Bank Negara Malaysia (2011) claims that this could in principle enhance monetary control and improve the cost-effectiveness of sterilisation in an environment of rising interest rates, as surplus liquidity is being absorbed at a lower rate for a longer period. Where capital inflows are strong and foreign investors are taking short-term positions in domestic currency, longer maturities could help avert some of the speculative inflows. Figure 3 shows the average maturity of outstanding sterilisation bonds for the different economies.

In most countries, the financial crisis brought about a decline in maturities in the face of FX depreciation pressures, and maturities have again increased lately. For Korea, there has been relatively little movement in the average maturity over time. In 2009, the share of MSBs with maturities less than 1 year rose, with the increase in the 91-day maturity being especially stark. In 2010, the maturity of outstanding bonds increased, with MSBs with maturities of at least one year gaining their share.

\footnotetext{
${ }^{10}$ Mohan (2008) suggests that the MSS is better than LAF in dealing with longer-term flows, and the CRR is appropriate for dealing with fairly long-term flows.
} 


\title{
Graph 3
}

\section{Average maturities of central bank bonds and bills}

\author{
In years
}

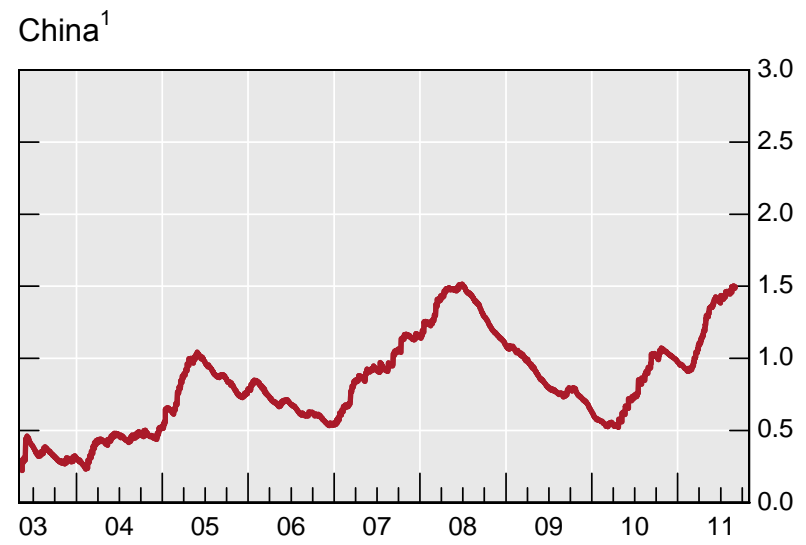

Indonesia ${ }^{2}$

Korea $^{2}$ and Malaysia ${ }^{1}$
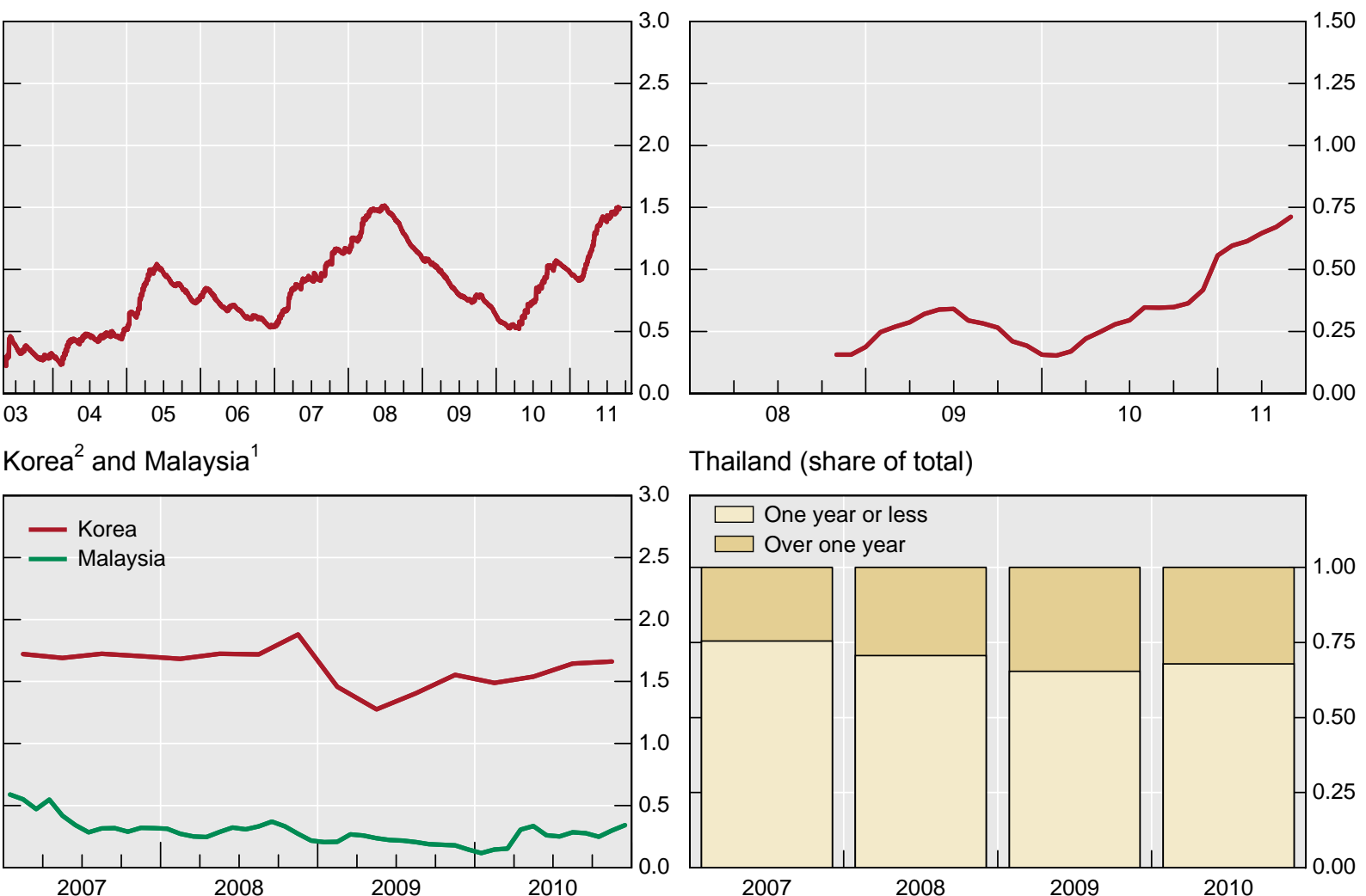

Thailand (share of total)

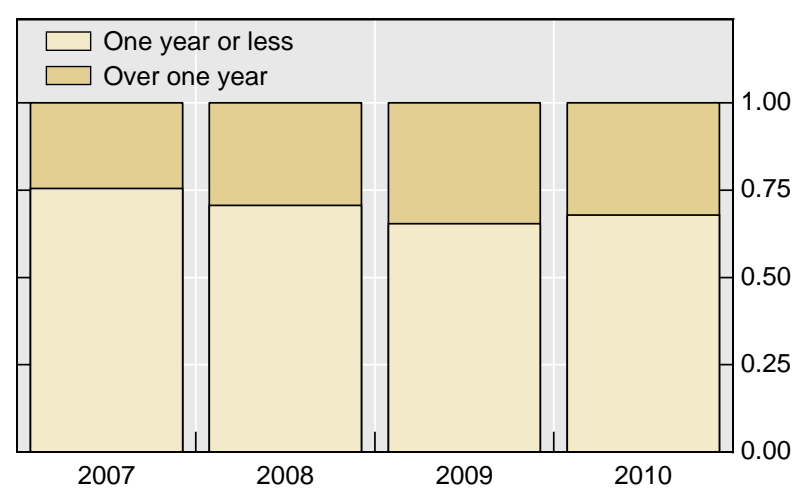

${ }^{1}$ Weighted average of remaining maturity by notional amount. For Malaysia, the series is computed by assuming that issuance takes place on the last day of each month. ${ }^{2}$ Average maturity of outstanding bills.

Sources: CEIC; national data; BIS calculations.

The maturity dynamics in Malaysia have been similar to the ones in Korea, although the average maturity has been shorter. The average maturity on new issues fell from close to half a year in 2007 to below four months in 2009, only to pick up again to over five months in $2010 .{ }^{11}$ In early 2008 , the BNMNs were used aggressively to mop up excess liquidity during periods of strong portfolio and trade flows (Bank Negara Malaysia, 2009). As concerns in the international financial system intensified, monetary operations were focused on shortening the average maturity of sterilisation operations. This was instrumental in an environment of strong portfolio outflows. The fall in the maturity for the central bank bills is in line with the fact that the average maturity for all monetary instruments declined from 39 days in April 2008 to 19 days by end-December 2008. The increase in the maturity period of sterilisation bonds coincided with the economic recovery of 2009-2010, and again went in hand with the increasing maturity profile of all monetary instruments (from 27 days in 2009 to 40 days in 2010).

\footnotetext{
${ }^{11}$ Prior to 2007, the average duration of outstanding Bank Negara Bills, Negotiable Notes, and Monetary Notes was gradually increasing (Table 2 in Sang Kuang, 2008). The average duration increased from 75 days in 2003 to 104 days in 2006.
} 
In China, the average maturity of outstanding bills has fluctuated notably. Three-year bills were issued between December 2004 and May 2005 and again in 2007, leading to a significant increase in the average maturity of both new issuance and outstanding bills. As the financial crisis hit, the PBoC halted the issuance of three-year bills in July 2008, resuming it again in April 2010.

The Bank Indonesia has also aimed at issuing longer-term paper (SBI) to deepen the monetary market and to encourage liquidity management from a longer-term perspective (Bank Indonesia, 2011). By July 2010, the amount of outstanding 1-month SBIs had dropped to zero. From September 2010 onwards, 3, 6 and 9-month SBls were issued, with a gradual reduction in outstanding 3-month SBIs. By January 2011, the amount outstanding of 3-month SBIs had fallen to zero as well. The average maturity of outstanding SBIs had increased from less than 3 months to over 6 months by early 2011 (Graph 3).

Similarly, in 2010, the Bank of Thailand aimed to lengthen the maturity profile of the Bank of Thailand bonds to "establish a more appropriate structure of the absorption tools" (Bank of Thailand, 2010, p. 90). Bonds with remaining maturities of 1 year or less still dominated the outstanding stock of central bank bonds (Graph 3), but their share fell from $75 \%$ in 2007 to $68 \%$ in 2010.

Mohanty and Turner (2006) suggest that if longer-term bills replace central bank bills with shorter maturity, this could have a longer-term impact on excess liquidity and enhance monetary control. The case of China provides an example. When the issuance of 3-year bills was resumed in 2007, the issuance of 1-year bills dropped from CNY2.5 trillion in 2006 to CNY1.6 trillion in 2007 (6-month bills fell from CNY95 billion in 2006 to zero in 2007). This coincided with increased monetary control to the extent that the PBoC was able to achieve its targets for broad money growth more closely. In particular, in 2007, the actual growth in broad money was $16.7 \%$, very close to the $16 \%$ target set by the PBoC. In contrast, in 2006 , actual growth in M2 was almost 3 percentage points higher than the target (16.9\% vs. 14\%), with relatively large deviations experienced also in 2003-2005. ${ }^{12}$

Evidence about the link between the level of monetary control and the increasing maturity structure can be also found for Indonesia. While Indonesia does not specify intermediate money growth targets, headline inflation rates have been falling throughout 2011 to levels consistent with the inflation target as the average maturities of outstanding central bank bills have increased.

The yields on sterilisation bonds have moved rather uniformly across countries (Graph 4). They fell as the financial crisis intensified in late 2008 - early 2009 . The yields have climbed notably in China from the levels witnessed during the crisis (from roughly 1 percent to over 3 percent), but remain relatively low. The yields paid on central bank bills in Korea and Thailand were at similar levels in mid-2011. Thailand has seen climbing yields since mid2010, but the differences between maturities have narrowed notably since 2009 (not shown). In Indonesia, the yields are higher across the maturity spectrum, but have remained very stable since 2009 .

\footnotetext{
${ }^{12}$ See Table 6 in Geiger (2008) and the statistical update at http://mgeiger.wordpress.com/statistics/ .
} 


\section{Graph 4}

\section{Yields on central bank bonds and bills}

In per cent

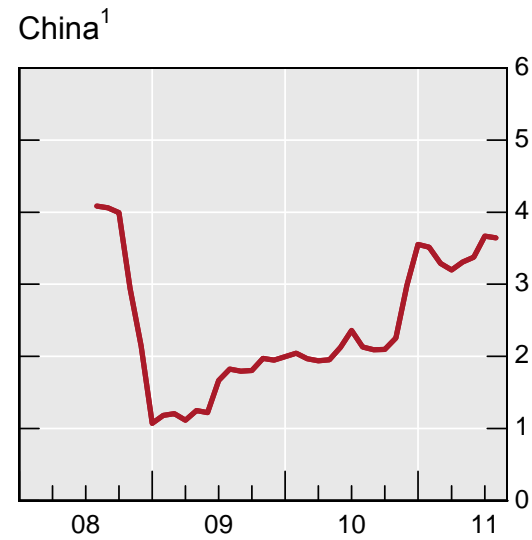

Indonesia and Malaysia ${ }^{2}$

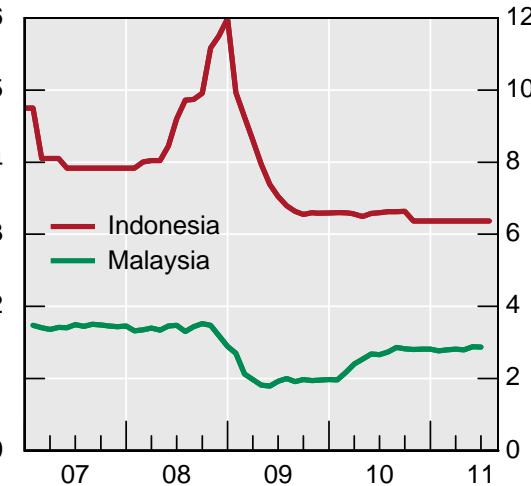

Korea and Thailand ${ }^{1}$

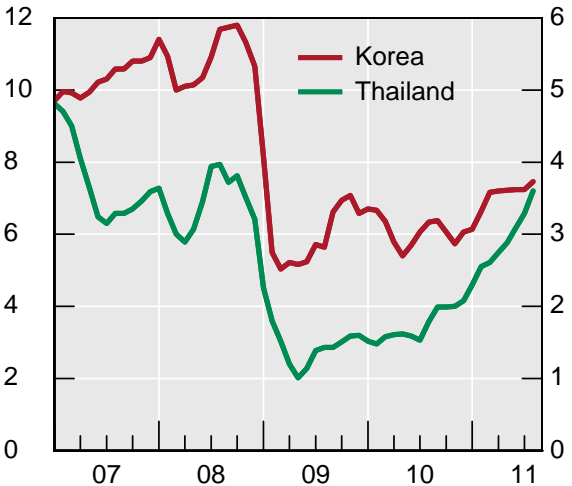

1 One-year yield. The series for Thailand includes T-Bills, Bank of Thailand bonds and Government bonds. ${ }^{2}$ Three- and six-month yields, respectively.

Sources: CEIC; national data.

Is there evidence of a proportionally higher share of sterilisation bonds being held by households and non-bank firms over time, in which case sterilisation would have become more complete? Data for Thailand suggest that the share of "other non-financial corporations", "public non-financial corporations", "households and non-profit institutions serving households" as holders of Bank of Thailand bonds increased from some $7 \%$ of total amount outstanding in 2007 to $15 \%$ in 2010. In the case of Indonesia, non-banks now hold a substantial share of SBIs (Table 3). The share has increased from 19.8 percent of outstanding SBls at end-2009 to 31.2 percent at end-2010. However, a very large part of non-bank holdings are in the hands of non-residents (88.1 percent at end-2010). This stands in contrast to Thailand, where non-resident holdings of BOT bonds have increased from $0.2 \%$ in 2007 to $0.7 \%$ in 2010 .

\begin{tabular}{|c|c|c|c|}
\hline \multicolumn{3}{|c|}{ Table 3} & \\
\hline & \multicolumn{2}{|c|}{ Non-bank holdings } & \multirow[t]{2}{*}{ Total outstanding } \\
\hline & Resident & Non-resident & \\
\hline end-2009 & 6.51 & 44.18 & 255.52 \\
\hline end-2010 & 7.43 & 54.93 & 200.11 \\
\hline
\end{tabular}

In the case of Korea, foreigners held slightly below $16 \%$ of outstanding MSBs at the end of 2010. And for Malaysia, with the exception of 2008 , between $32 \%$ and $52 \%$ of total outstanding Bank Negara Bills and Monetary Notes have been held by non-residents in recent years (Table 4$)$. 


\begin{tabular}{|c|c|c|}
\hline \multicolumn{3}{|c|}{ Central bank securities } \\
\hline \multirow{2}{*}{} & Non-resident holdings & Total outstanding \\
\cline { 2 - 3 } & \multicolumn{2}{|c|}{ MYR millions } \\
\hline 2007 & $36,065.8$ & $69,010.0$ \\
\hline 2008 & $4,165.4$ & $43,710.2$ \\
\hline 2009 & $11,923.9$ & $33,357.4$ \\
\hline 2010 & $31,623.7$ & $100,376.8$ \\
\hline Source: Bank Negara Malaysia Monthly Statistical Bulletin. \\
\hline
\end{tabular}

\section{Choice of sterilisation instrument and macroeconomic conditions}

The choice of a sterilisation method for a central bank depends, in addition to its relative merits, on the conjuncture of financial and economic factors (BIS, 2009). In this section, we investigate under what macroeconomic and financial conditions selected central banks in Asia have mopped up liquidity from the financial system by issuing central bank paper rather than by increasing reserve requirements. While both methods could be used to freeze liquidity simultaneously, their relative importance could vary across time and as external conditions change. The use of the non-market based instrument of reserve requirements has been prominent during the recovery especially in the case of China, but changes in the reserve requirement ratio have been applied also in India, Indonesia and Malaysia.

In order to investigate the issue, we estimate a reaction function for each central bank in our sample, of the following form:

$B_{t} / R R_{t}=a_{0}+a_{1} y_{t}+a_{2} \pi_{t}+a_{3}$ credit $_{t}+a_{4} k_{t}^{\text {bond }}+a_{5} k_{t}^{\text {equity }}+a_{6} i^{\text {diff }}{ }_{t}+a_{7}\left(B_{t-1} / R R_{t-1}\right)+\varepsilon_{t}$.

In (1), $B_{t} / R R_{t}$ denotes the outstanding stock of sterilisation bills, relative to required reserves (both measured in domestic currency). ${ }^{13}$ Regarding the macroeconomic conditions, $y_{t}$ denotes output growth, $\pi_{t}$ is inflation, and credit $t_{t}$ captures the growth in domestic credit. Capital inflows are taken into account by two separate variables, expressed in domestic currency and as ratios to GDP, with $k_{t}^{\text {bond }}$ capturing bond inflows and $k_{t}^{\text {equity }}$ equity inflows. The interest cost to the central bank from using central bank paper relative to using reserve requirements for sterilisation is captured by including the difference of the yield on central bank paper and the rate of remuneration on required reserves, $i_{t}^{\text {diff }}$. Persistence in the relative use of the two instruments is allowed for by including a lagged measure of the dependent variable $B_{t-1} / R R_{t-1}$.

The inclusion of output growth and inflation can be justified on the basis of standard aims of output and inflation stabilisation in a central bank objective function, while the consideration

${ }^{13}$ For China and Malaysia, the dependent variable is the ratio of increase in absorption by the two instruments (where the increase is specified as the amount of newly issued paper in the case of the numerator). This is done due to the time series properties of the series, in particular the consideration of having a stationary series for the estimation. 
of credit growth can be motivated by monetary and financial stability concerns. ${ }^{14}$ The latter has gained in importance especially after the international financial crisis, as central banks have been granted new tasks in the areas of macroprudential policies and supervision. Regarding the composition of capital flows, Aizenman and Glick (2009) find that the sterilisation response varies with the composition of inflows. As the cost of sterilisation is likely to increase as the volume of issuance increases, the central bank may be increasingly reluctant to issue central bank paper and possibly choose to increase the reserve requirement ratio. This phenomenon is captured by including the difference between the yield on central bank securities and the rate of remuneration on required reserves in the regression.

We note that possible statistically insignificant coefficients on some of the right-hand side variables in (1) do not imply that the central bank would not regard these variables as important for its sterilisation policy. Indeed, if the central bank would resort to increased issuance of central bank bills and hikes in reserve requirements in roughly equal measure in the face of capital inflows, this could show as statistically insignificant coefficients for the capital inflow variables. Moreover, the central bank may address any concerns of excess liquidity or, more broadly, macroeconomic and financial instability by using other instruments, such as repo contracts. While it would be preferable to use capital flow data in line with the balance-of-payments concept, these data are not available on a monthly frequency. Therefore, portfolio flow data from EPFR funds were employed. These provide a good description of the overall dynamics of portfolio flows, but they only capture a fraction of the total flows (see Jotikasthira et al., 2010). The data in question are the net inflows to EPFR equity and bond funds for each month.

Table 5 presents the estimation results for Equation (1), using a Generalised Method of Moments (GMM) estimator. Our sample is limited to economies in emerging Asia where both issuance of central bank paper and relatively frequent changes in reserve requirements took place during the time period under study. In the case of India, as the central bank cannot issue its own securities, we use the amount of liquidity held at the MSS cash account at the Reserve Bank as a measure of liquidity absorbed by bill issuance (see Section 3).

Some stylised facts emerge from the estimations. First, higher growth in domestic credit is associated with increased use of central bank bills rather than reserve requirements for absorbing liquidity. The other variables associated with macroeconomic conditions matter much less, although we do find a statistically significant positive coefficient for the inflation rate in the case of Malaysia. Second, regarding capital inflows, there is no statistically significant association between either equity or bond inflows and the choice between the sterilisation instruments - both seem to be used in equal measure in the face of portfolio inflows. Third, the relative cost of using the instruments obtains the expected sign coupled with a statistically significant coefficient only in the case of Malaysia. That is, when the cost of issuing central bank securities increases relative to the rate of remuneration of reserve requirements, the use of reserve requirements as a tool to absorb liquidity increases. Finally, there is statistically significant inertia in the choice of sterilisation instruments for all the economies under study. ${ }^{15}$

14 The underlying issue facing the central bank is not one of aggregate demand, but the control of liquidity. Nevertheless, macroeconomic conditions matter, as they may impact on the magnitude of sterilisation (eg deflationary pressures could call for less than full sterilisation of capital inflows). Similarly, the strength of capital inflows may matter for the choice of the sterilisation instrument - higher reserve requirements could depress deposit rates and therefore help in avoiding excessive inflows (see Montoro and Moreno, 2006).

${ }^{15}$ When the change in the combined liquidity absorbed by the two instruments is used as the dependent variable $\Delta\left(B_{t}+R R_{t}\right)$, and omitting $i^{\text {diff }}{ }_{t}$ from the estimation, one would expect more coefficients to obtain statistically significant coefficients than in the benchmark estimation (Table 5). For China, this is indeed the case - 


\begin{tabular}{|c|c|c|c|c|}
\hline \multicolumn{5}{|c|}{$\begin{array}{c}\text { Table } 5 \\
\text { Determinants of choice of sterilisation instrument }\end{array}$} \\
\hline & China & Indonesia & Malaysia & India \\
\hline Industrial production & $\begin{array}{c}0.001 \\
(0.003)\end{array}$ & $\begin{array}{l}-0.002 \\
(0.004)\end{array}$ & $\begin{array}{l}-0.229 * * \\
(0.092)\end{array}$ & $\begin{array}{l}\text { 1.69E-05 } \\
(0.003)\end{array}$ \\
\hline Inflation & $\begin{array}{l}0.001 \\
(0.004)\end{array}$ & $\begin{array}{c}0.002 \\
(0.008)\end{array}$ & $\begin{array}{l}0.021^{* * *} \\
(0.006)\end{array}$ & $\begin{array}{l}-0.001 \\
(0.003)\end{array}$ \\
\hline Domestic credit & $\begin{array}{l}0.547^{* *} \\
(0.220)\end{array}$ & $\begin{array}{l}-0.040 \\
(0.417)\end{array}$ & $\begin{array}{l}3.513^{*} \\
(1.912)\end{array}$ & $\begin{array}{l}2.564^{* * *} \\
(0.659)\end{array}$ \\
\hline Equity inflows & $\begin{array}{l}-0.005 \\
(0.009)\end{array}$ & $\begin{array}{c}0.019 \\
(0.044)\end{array}$ & $\begin{array}{c}2.177 \\
(7.536)\end{array}$ & $\begin{array}{c}0.005 \\
(0.007)\end{array}$ \\
\hline Bond inflows & $\begin{array}{l}0.258 \\
(0.500)\end{array}$ & $\begin{array}{c}0.038 \\
(0.024)\end{array}$ & $\begin{array}{c}9.829 \\
(12.595)\end{array}$ & $\begin{array}{c}0.066 \\
(0.273)\end{array}$ \\
\hline $\begin{array}{l}\text { Lagged ratio of liquidity } \\
\text { absorption }\end{array}$ & $\begin{array}{c}0.654^{* * *} \\
(0.254)\end{array}$ & $\begin{array}{c}0.838^{* * *} \\
(0.148)\end{array}$ & $\begin{array}{c}0.426^{* * *} \\
(0.069)\end{array}$ & $\begin{array}{c}0.776^{* * *} \\
(0.078)\end{array}$ \\
\hline Return spread & $\begin{array}{c}0.004 \\
(0.017)\end{array}$ & $\begin{array}{l}-0.011 \\
(0.014)\end{array}$ & $\begin{array}{c}-0.352^{* * *} \\
(0.042)\end{array}$ & $\begin{array}{c}0.037^{\star * *} \\
(0.009)\end{array}$ \\
\hline Adj. R squared & 0.432 & 0.591 & 0.819 & 0.953 \\
\hline $\begin{array}{l}\text { Note: Generalised method of } m \\
\text { bank bills to liquidity absorbed } \\
\text { specified as y-o-y growth rates; } \\
\text { heteroskedasticity consistent } \\
\text { 2005M4-2010M6; Malaysia: } 200\end{array}$ & $\begin{array}{l}\text { estimates } \\
\text { juirements } \\
\text { d inflows } \\
\text { in pare }\end{array}$ & $\begin{array}{l}\text { lent variable } \\
\text { ial producti } \\
\text { as ratios to } \\
\text { Samples: }\end{array}$ & $\begin{array}{l}\text { of liquidity } \\
\text { flation and } \\
\text { Constant } \\
\text { 2008M1- }\end{array}$ & $\begin{array}{l}\text { bed by centra } \\
\text { stic credit are } \\
\text { splayed. White } \\
\text { 14; Indonesia }\end{array}$ \\
\hline
\end{tabular}

industrial production, inflation, loans and net portfolio inflows to bond funds all now obtain positive and statistically significant coefficients (at a minimum of $10 \%$ level). Moreover, for all economies, net portfolio inflows to bond funds now obtain statistically significant and positive coefficients. 
A feature in sterilisation bond issuance in recent times is the aim by central banks to increase the maturities of the issued securities. Do the explanatory variables used in Table 5 prove useful in explaining changes in the maturities of issued sterilisation bonds? Strong economic overheating or expected capital inflows could prompt the central bank to lengthen the maturity of issuance if surplus liquidity is expected for a longer period of time.

\begin{tabular}{|c|c|c|c|}
\hline \multicolumn{4}{|c|}{$\begin{array}{c}\text { Table } 6 \\
\text { Determinants of maturity of central bank bills }\end{array}$} \\
\hline & China & Indonesia & Malaysia \\
\hline Industrial production & $\begin{array}{c}0.012 \\
(0.026)\end{array}$ & $\begin{array}{c}0.001 \\
(0.004)\end{array}$ & $\begin{array}{l}0.190^{* *} \\
(0.083)\end{array}$ \\
\hline Inflation & $\begin{array}{c}0.051 \\
(0.035)\end{array}$ & $\begin{array}{l}0.011^{* *} \\
(0.005)\end{array}$ & $\begin{array}{l}0.011^{* * *} \\
(0.003)\end{array}$ \\
\hline Domestic credit & $\begin{array}{c}0.961 \\
(2.630)\end{array}$ & $\begin{array}{l}-0.047 \\
(0.200)\end{array}$ & $\begin{array}{l}-0.783 \\
(0.797)\end{array}$ \\
\hline Equity inflows & $\begin{array}{l}0.086^{*} \\
(0.044)\end{array}$ & $\begin{array}{l}-0.006 \\
(0.010)\end{array}$ & $\begin{array}{l}-2.342 \\
(2.826)\end{array}$ \\
\hline Bond inflows & $\begin{array}{c}1.027 \\
(4.406)\end{array}$ & $\begin{array}{c}0.006 \\
(0.014)\end{array}$ & $\begin{array}{l}12.965^{\star * *} \\
(3.479)\end{array}$ \\
\hline Lagged maturity & $\begin{array}{l}0.601^{* * *} \\
(0.137)\end{array}$ & $\begin{array}{l}0.940^{* * *} \\
(0.099)\end{array}$ & $\begin{array}{l}0.636^{* * *} \\
(0.104)\end{array}$ \\
\hline Interest rate spread & $\begin{array}{c}0.048 \\
(0.042)\end{array}$ & $\begin{array}{c}0.049 \\
(0.060)\end{array}$ & $\begin{array}{l}-0.045 \\
(0.034)\end{array}$ \\
\hline Adj. R squared & 0.596 & 0.949 & 0.704 \\
\hline $\begin{array}{l}\text { Note: Generalised Method of } \\
\text { of central bank bills. Industrial } \\
\text { rates; equity and bond inflo } \\
\text { heteroskedasticity consistent } \\
\text { Indonesia: } 2009 \mathrm{M} 2-2011 \mathrm{M} 3 ; \mathrm{M}\end{array}$ & $\begin{array}{l}\text { estimates } \\
\text { on and dc } \\
\text { s ratios } \\
\text { in parentl } \\
2011 \mathrm{M} 3 \text {. }\end{array}$ & $\begin{array}{l}\text { lent variable } \\
\text { redit are spe } \\
\text { Constant } \\
\text { amples: Ch }\end{array}$ & $\begin{array}{l}\text { anding matur } \\
\text { as y-o-y grow } \\
\text { played. Whi } \\
\text { 08M1-2011M }\end{array}$ \\
\hline
\end{tabular}


We run the models reported in Table 5 for China, Indonesia and Malaysia with the average maturity of central bank bills as the dependent variable (average outstanding for Indonesia, average remaining for China and Malaysia; see Graph 3), and including its first lag as a regressor to capture inertia in the choice of maturity structure. We also include an interest rate spread between a short-term interest rate and the longer-term rate on central bank paper. $^{16}$

For both Indonesia and Malaysia, we find that higher inflation is positively associated with an increase in the maturity of sterilisation bills (at $5 \%$ level). Therefore, increases in maturities could have indeed been aimed at increasing monetary control. Similarly, for Malaysia, higher growth in industrial production is also positively associated with increases in maturity, with a statistically significant coefficient. We also find some evidence of stronger portfolio inflows being associated with longer maturities, as expected. This holds for equity inflows in the case of China (albeit only at 10\% level) and bond inflows in the case of Malaysia. As in the case of the choice of sterilisation instruments, cost considerations in the form of the spread between long-term and short-term interest rate seems to play little role. Finally, for all three economies, lagged values of maturity are always statistically significant, suggesting only gradual changes in the maturity structure over time.

Finally, we consider the possible interaction between the two different sterilisation instruments, the issuance of sterilisation securities and changes in reserve requirement ratios. Obviously, these two measures could be used as substitutes when withdrawing excess liquidity, in which case an econometric analysis may suggest that there is no relationship between the levels of the two variables. They could also complement each other - the central bank may consider increased paper issuance appropriate after adjusting reserve requirements, especially if the latter have been increased frequently and are already high, and the need to mop up excess liquidity remains. Similarly, if the amount of outstanding sterilisation securities in the hands of the banking sector is already considered too high and possibly interferes with the bank lending channel, the monetary authority may prefer adjusting the reserve requirement ratio instead.

We estimate a vector autoregressive model including the issuance of sterilisation paper, reserve requirement ratio, together with output growth and inflation. The focus of the analysis is on the interaction between sterilisation bond issuance and reserve requirement ratios, investigated by impulse response analysis, introducing a shock to one of the instruments and tracing the effects of the shock through the system. ${ }^{17}$ Due to considerations of having a sufficient sample length and data on the use of both instruments, the analysis is limited to China and Indonesia.

We find that for China, a positive shock to the issuance of sterilisation bills actually leads to a statistically significant fall in the reserve requirement ratio (Graph 5). This result is likely driven by the dynamics experienced in 2010-11. During this period, reduced issuance of central bank bills, evident in the declining stock of outstanding bills in Graph A3, coincided with frequent increases in the reserve requirement ratio to mop us excess liquidity and contain inflation pressures. The reduced bill issuance may have partly stemmed from the increase in bill yields at that time (Graph 4), while required reserves continued to be remunerated at $1.62 \%$ p.a. In contrast, bond issuance does not react in a statistically

${ }^{16}$ The short-term interest rate is the 14 day repo rate for China, and the overnight rate for Indonesia and Malaysia. For central bank paper, we use the rate on 1-year maturity for China, six-month maturity for Malaysia and 3-month maturity for Indonesia.

172 lags are used in the VARs for China (quarterly data), and 9 lags for Indonesia (monthly data). The shocks are orthogonalised by the conventional Cholesky decomposition. Regarding the order of the variables, output and inflation are ordered first, reflecting the inertia of these variables. This is followed by the two policy instruments, with the required reserve ratio ordered before the sterilisation bond issuance. 
significant manner to shocks in the reserve requirement ratio. In the case of Indonesia, the results are less straightforward; while some statistically significant impacts are found for both shocks, the responses fluctuate mostly near the zero line. However, even for this economy, there is some evidence of a negative response of the required reserve ratio to positive shocks to bond issuance in the long run.

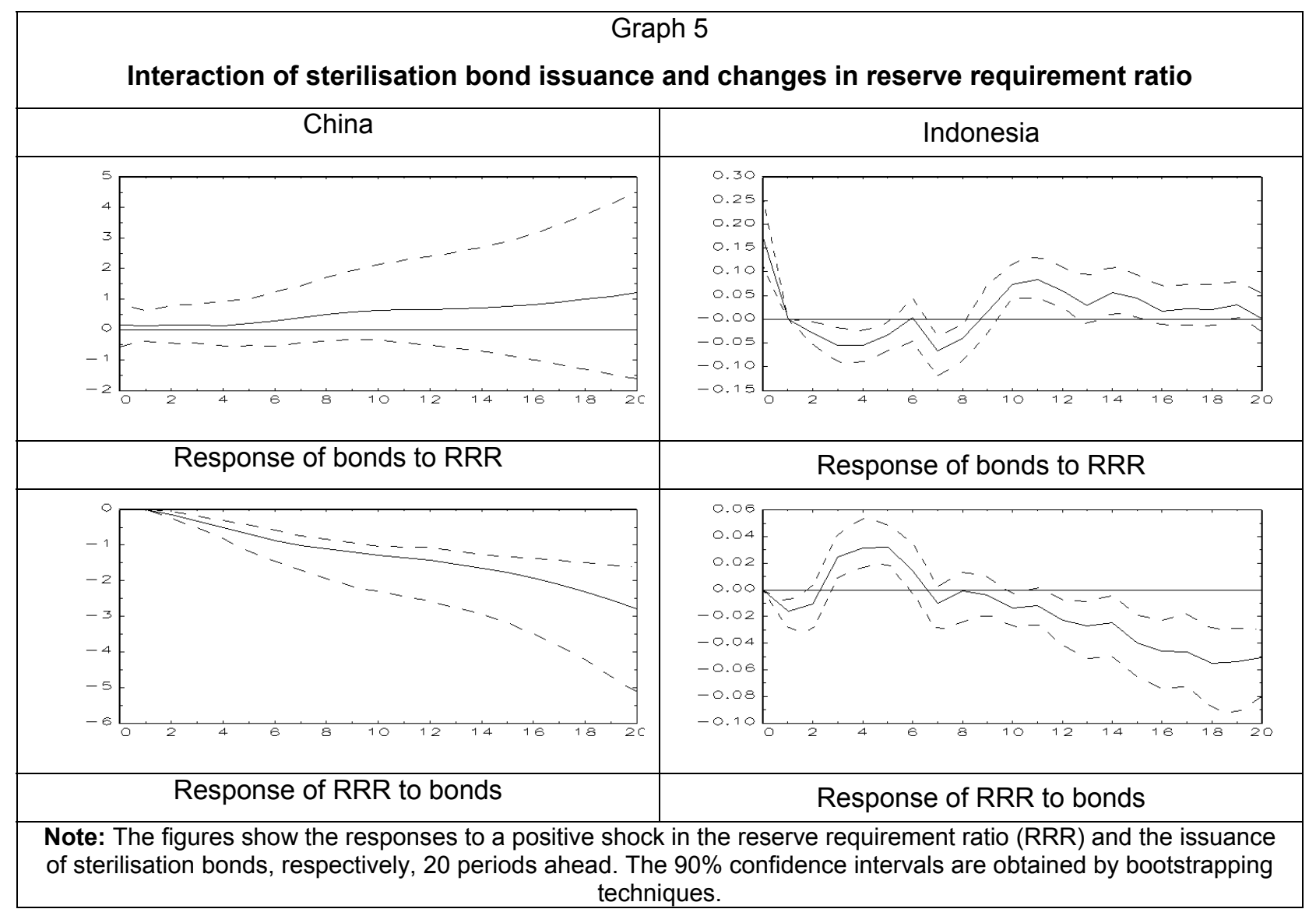

\section{Conclusion and policy implications}

In this paper, we have investigated the issuance of sterilisation bonds in emerging Asia. An important development in recent years in the conduct of sterilisation has been the issuance of central banks' own paper. While some central banks in the region, such as Indonesia and Korea, have a longer history in issuing their own paper, the stock of outstanding central bank bills has increased rapidly in recent years. This partly reflects the increase in net foreign assets in central bank balance sheets, ie the sterilisation need has increased, and partly the deepening of the local financial markets that has supported the move to market-based methods for sterilisation.

We document that while the average maturities of outstanding bonds fell during the international financial crisis, maturities have lengthened across the board in 2010-11. This is consistent with the aims of monetary authorities in many jurisdictions, and is argued by some central banks to enhance monetary control. The average maturities in our sample at end2010 were longest in China and Korea, and the sharpest increases in maturities have recently been experienced in China and Indonesia. Yields on central bank bills have increased during the past year especially in China and Thailand, and they have been rather flat in both Indonesia and Malaysia. 
Regarding the macroeconomic and financial environment, an econometric analysis suggests that sterilisation bond issuance, relative to increases in reserve requirements, has been used to absorb liquidity especially when credit growth is high. Moreover, maturities of central bank securities have increased especially when inflation is high, suggesting that monetary stability considerations have played a role in the maturity structure of issued securities.

What implications do our findings have for policymakers? The increase in maturities is encouraging, as it may help to withdraw excess liquidity for a longer period especially in an environment of persistent capital inflows. Evidence from China suggests that the increased issuance of longer-term bills has coincided with increased monetary control in terms of meeting the intermediate money growth targets. Inflation has approached the central bank's inflation target in Indonesia as maturities have increased during 2010-11. In principle, the increase in maturities should also facilitate effective sterilisation through the increased attractiveness of sterilisation paper.

However, sterilisation through issuance of central bank paper is fully effective only when households and non-bank firms are the ultimate holders of sterilisation paper, as this would reduce the broad money stock in the economy. While non-bank holdings are substantial for example in the case of Indonesia, a large part of these holdings are by non-residents. Similarly, non-resident holdings have been large in Malaysia. This underlines the challenges of sterilisation using securities with relatively short maturities, as they may attract further capital inflows into the economy and run against the aim of sterilisation.

As sterilisation bonds are market-based instruments, their increased use should have already lowered the possibility that sterilised intervention would add to distortions in the economy. Moreover, the increased stock of central bank paper has added to the depth of the bond markets and helped further develop a yield curve. However, if higher yields on central bank bills lead to increasing sterilisation costs, and the bank lending channel itself is affected by a high outstanding stock of central bank paper, the monetary authority may be inclined to increasingly return to non-market based sterilisation instruments. We find some preliminary evidence for this, as there seems to be a negative relationship between bond issuance and the adjustment of reserve requirement ratios for some economies in the sample. As liquidity absorption through central bank bills increases especially as credit growth is high, and these securities are relatively liquid from the commercial banks' viewpoint, financial stability considerations imply that attention should be paid to the growth of the stock of central bank paper.

Finally, given the very uneven global growth prospects and the associated capital inflows into emerging Asia, there is little evidence to suggest that sterilisation through the issuance of central bank securities would assume a smaller role in the years to come.

\section{References}

Aizenman, J and R Glick (2009): "Sterilisation, Monetary Policy, and Global Financial Integration", Review of International Economics 17(4), 777-801.

Aizenman, J and J Lee (2007): "International Reserves: Precautionary Versus Mercantilist Views, Theory and Evidence", Open Economies Review 18(2), 191-214.

Bank for International Settlements (2009): "Capital flows and emerging market economies", CGFS Papers, no 33.

Bank Indonesia (2011): "2010 Economic Report on Indonesia”.

Bank Negara Malaysia (2009): "Annual Report 2008”

Bank Negara Malaysia (2011): "Annual Report 2010"

Bank of Korea (2010): "Annual Report" 
Bank of Thailand (2011): "Annual Economic Report 2010"

Bank of Thailand (2010): "Annual Economic Report 2009"

Cook, D and J Yetman (2011): "Expanding central bank balance sheets in emerging Asia: a compendium of risks and some evidence", mimeo.

Filardo, A and S Grenville (2011): "Central bank balance sheets and foreign exchange rate regimes: understanding the nexus in Asia", mimeo.

Geiger, M (2008): "Instruments of Monetary Policy in China and Their Effectiveness: 19942006", UNCTAD Discussion Papers, no. 187.

$\mathrm{He}, \mathrm{D}, \mathrm{C}$ Chu, C Shu and A Wong (2005): "Monetary Management in Mainland China in the Face of Large Capital Inflows", Research Memorandum No.07/2005, Hong Kong Monetary Authority.

Jotikasthira, C., C T Lundblad, and T Ramadorai (2010): "Asset Fire Sales and Purchases and the International Transmission of Financial Shocks", CEPR Discussion Paper No. 7595.

Kumhof, M (2004): Sterilisation of Short-Term Capital Inflows - Through Lower Interest Rates? Journal of International Money and Finance 23(7-8), 1209-1221.

Ma, G, X Liu and X Yan (2011): "China's evolving reserve requirements", mimeo.

Mohan, R (2008): "Capital flows to India”, BIS Papers, no. 44.

Mohanty, M S and P Turner (2006): "Intervention: what are the domestic consequences?", BIS Papers, no 24.

Montoro, C and R Moreno (2011): "The use of reserve requirements as a policy instrument in Latin America", BIS Quarterly Review, March, 53-65.

Ouyang, A Y, Rajan, R S and T D Willett (2007): "China as a reserve sink: The evidence from offset and sterilisation coefficients", HKIMR Working Paper No. 10/2007.

Reinhart, C and V Reinhart (1999): "On the use of reserve requirements in dealing with capital flow problems", International Journal of Finance and Economics, 4(1), 27-54.

Sang Kuang, $O$ (2008): "Capital flows and financial assets in emerging markets: determinants, consequences and challenges for central banks: the Malaysian experience", BIS Papers, no 44.

Thaicharoen, Y and N Ananchotikul (2008): "Thailand's experiences with rising capital flows: recent challenges and policy reponses", BIS Papers, no 44. 


\section{Appendix}

\section{Graph A1}

\section{Foreign exchange reserves minus currency held by the public}

As a percentage of:

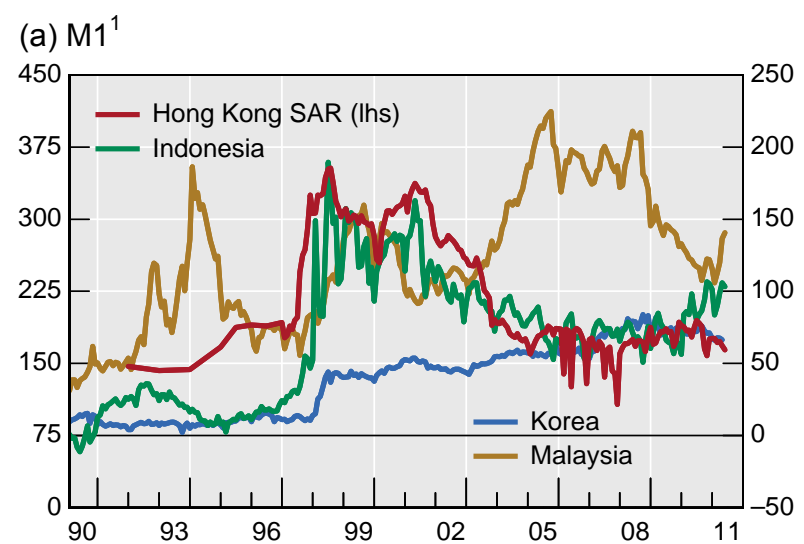

(b) $\mathrm{M}^{2}$

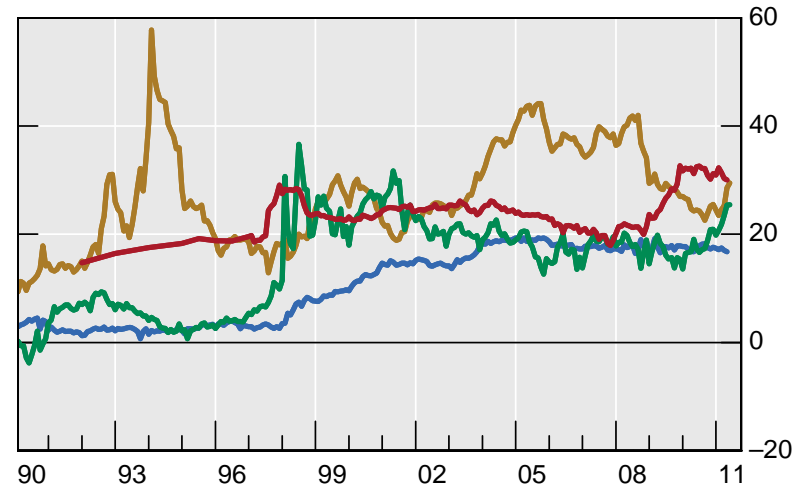

(c) Bank credit to the private sector

(d) Public sector domestic debt securities
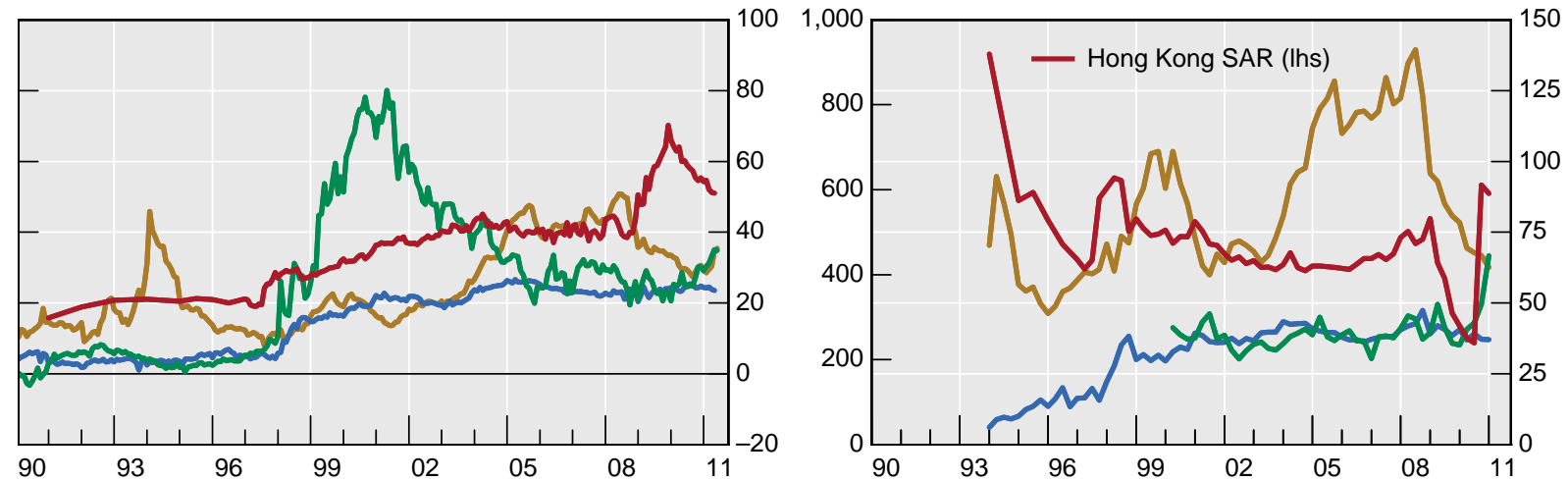

$1 \mathrm{M} 1$, also called narrow money, comprises transferable deposits and currency outside deposit money banks. 2 M2 is a broad measure of money which in general comprises, in addition to M1, time, savings and foreign currency deposits of resident sectors other than central government. The components can vary across economies.

Sources: IMF; Datastream; national data; BIS. 


\section{Graph A2}

\section{Foreign exchange reserves minus currency held by the public}

As a percentage of:

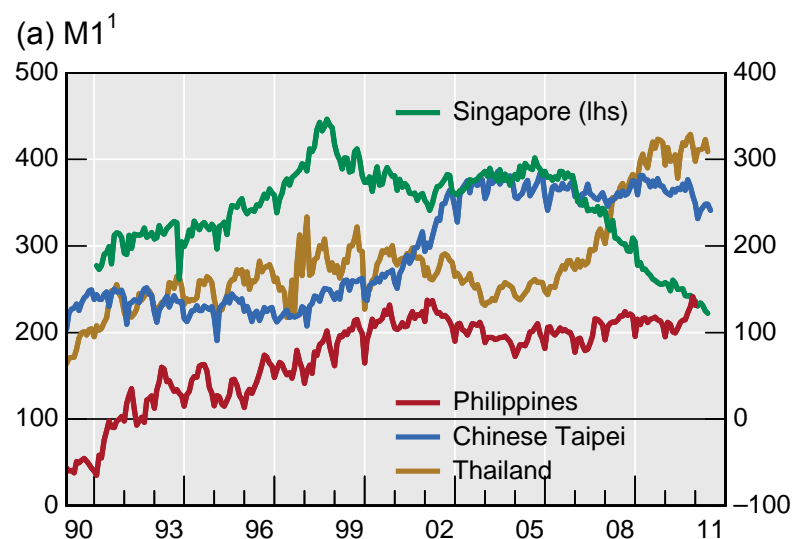
(b) $\mathrm{M}^{2}$

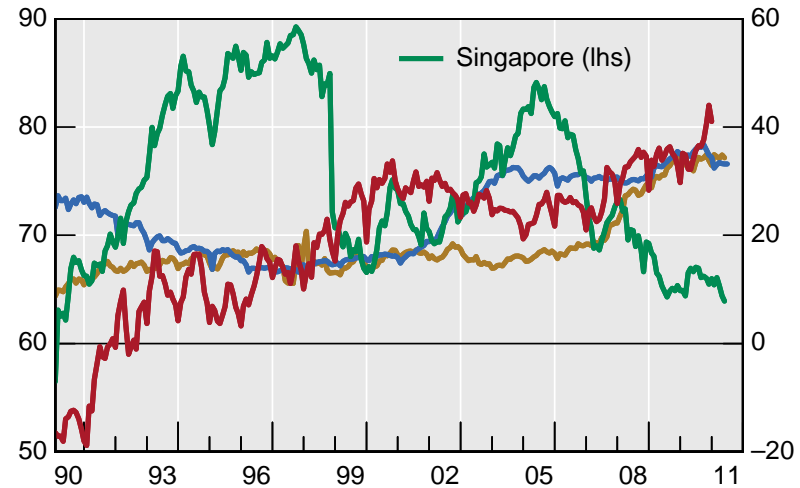

(c) Bank credit to the private sector

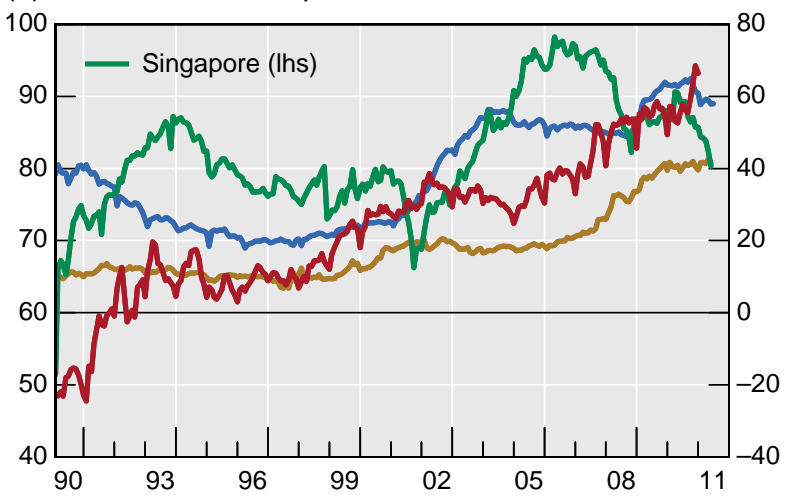

(d) Public sector domestic debt securities

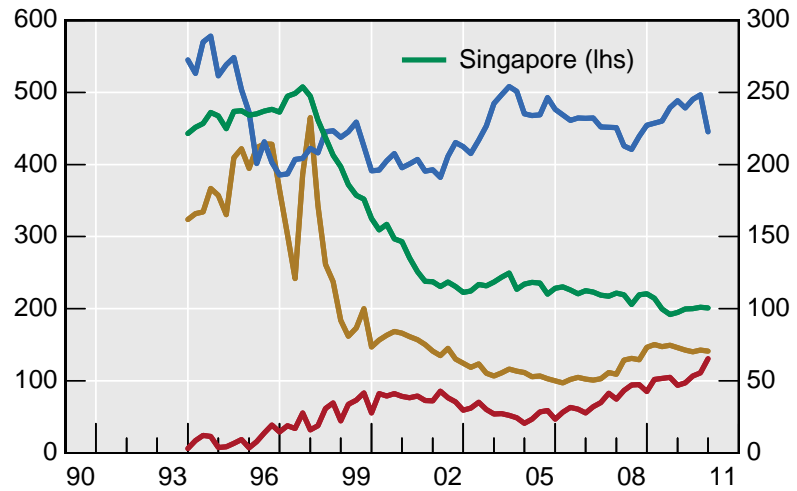

${ }^{1} \mathrm{M} 1$, also called narrow money, comprises transferable deposits and currency outside deposit money banks. ${ }^{2}$ M2 is a broad measure of money which in general comprises, in addition to M1, time, savings and foreign currency deposits of resident sectors other than central government. The components can vary across economies.

Sources: IMF; Datastream; national data; BIS. 


\section{Graph A3}

\section{Central bank securities ${ }^{1}$}

In billions of national currency ${ }^{2}$

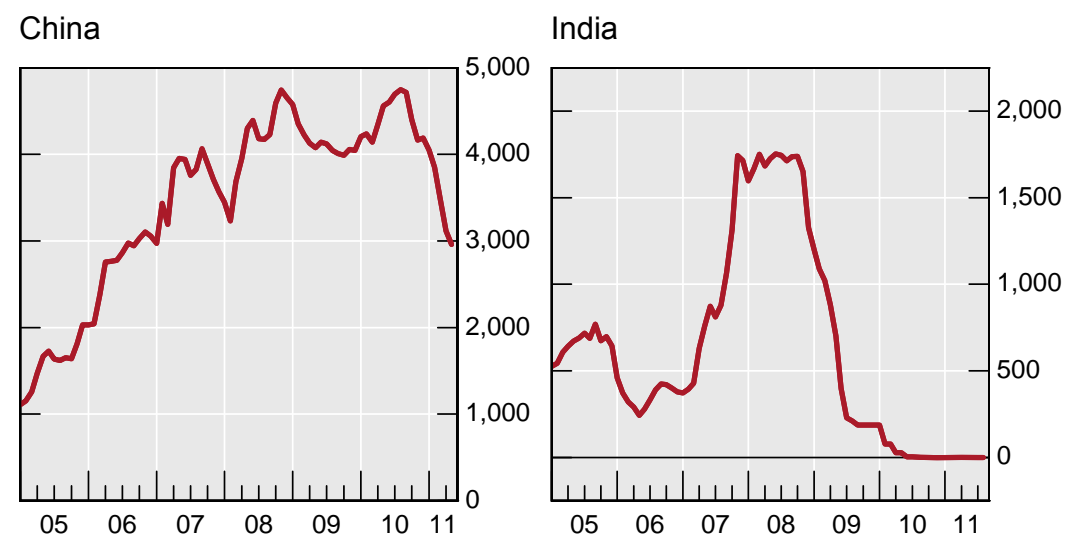

Indonesia

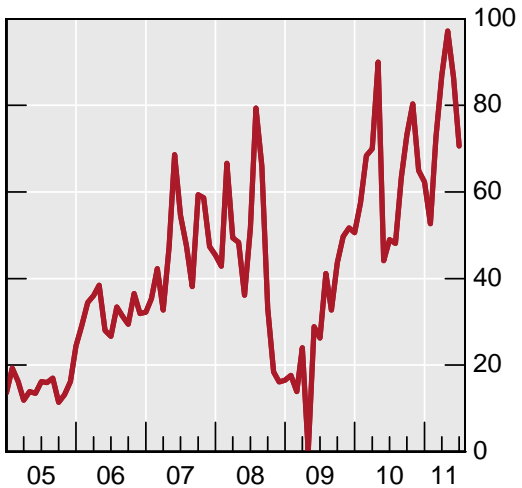

Thailand

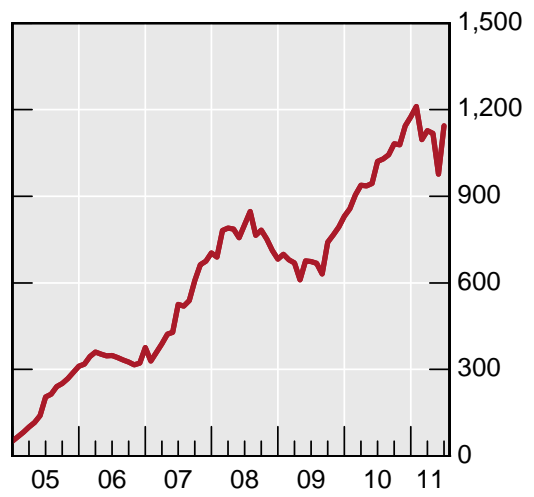

${ }^{1}$ For India, proceeds from auctions of treasury bonds and securities under the market stabilization scheme, deposited at the Reserve Bank of India. ${ }^{2}$ For Indonesia and Korea, in trillions.

Sources: IMF; CEIC. 